\title{
The Relationship of Hemoglobin, Interleukin-10 and Tumor Necrosis Factor Alpha Levels In Asymptomatic Malaria Patients in Trenggalek, Jawa Timur, Indonesia
}

\author{
Arif Rahman Nurdianto ${ }^{1,2,3}$, Heny Arwati ${ }^{4}$, Yoes Prijatna Dachlan ${ }^{4}$, Dyah Ayu Febiyanti ${ }^{5}$ \\ ${ }^{1}$ Faculty of Medicine, Airlangga University, Surabaya, Indonesia \\ ${ }^{2}$ Public Health Office of Sidoarjo, Sidoarjo, Indonesia \\ ${ }^{3}$ Institute of Health Science, Anwar Medika General Hospital, Sidoarjo, Indonesia \\ ${ }^{4}$ Department of Parasitology, Faculty of Medicine, University of Airlangga, Surabaya, Indonesia \\ ${ }^{5}$ General Hospital of Sidoarjo, Sidoarjo, Indonesia
}

Background: Malaria is still a universal health problem, especially in tropical countries because of high morbidity and mortality rates. Infection by Plasmodium falciparum and Plasmodium vivax could result in asymptomatic disease of malaria and be found in Trenggalek, Jawa Timur. Differences in pathogenesis among affected individuals are affected by many factors, and the immune system is one of them. Among substances involved in the malarial immunity is Tumor Necrosis Factor (TNF)- $\alpha$ and Interleukin (IL)-10, produced by the body's defense system as the reaction to the parasite. Therefore a study was designed to detect the level of TNF- $\alpha$ and IL-10 in asymptomatic malaria patients.

Materials and Methods: A cross-sectional study was conducted. Thirty male asymptomatic malaria subjects, age 21 to 60 years were selected. Blood from each subject was collected and the levels of TNF- $\alpha$ and IL-10 were analyzed using enzymelinked immunosorbent assay (ELISA) method. Significant values considered at $p<0.05$.

Results: There was an increased level of TNF- $\alpha$ with the average of $218.760 \mathrm{pg} / \mu \mathrm{L}$, and an increased level of IL-10 with an average of $257.574 \mathrm{pg} / \mu \mathrm{L}$ in asymptomatic malaria subjects. In normal person IL-10 level is 12.6 (8.5-16.7) pg/mL and the levels of TNF- $\alpha$ in normal person is $0-1.5 \mathrm{pg} / \mathrm{mL}$ because they are not produce. There was a positive correlation of TNF- $\alpha$ with IL-10 ( $r=0.332 ; p>0.05)$, and positive correlation between TNF- $\alpha$ and the rate of hemoglobin ( $r=0.002 ; p>0.05)$ IL-10 was correlated negatively with the rate of hemoglobin $(r=-0.363 ; p<0.05)$.

Conclusion: The results from this study conclude that TNF- $\alpha$ and IL-10 levels increase in asymptomatic malaria subjects.

Keywords: asymptomatic malaria, TNF- $\alpha$, IL-10, parasite, hemoglobin

\section{Introduction}

In 2012, malaria cases was reported in 31 districts and cities in the Jawa Timur Province. The highest number of cases was in Trenggalek Regency with 310 number of cases. The Case of imported malaria in Jawa Timur is up to $93.8 \%$ or 1,320 people and the indigenous cases were $6.2 \%$ or as many as 9 people. ${ }^{1}$

Date of submission: September 132018

Last Revised: September 26, 2018

Accepted for publication: October 5, 2018

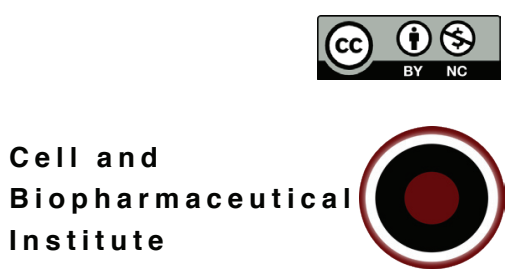

Corresponding Author:

Arif Rahman Nurdianto

Faculty of Medicine, Airlangga University

Jl. Mayjen Prof. Dr. Moestopo No.47, Surabaya, Indonesia

E-mail: didins99@gmail.com 
The pathogenesis of anemia in malaria involves the immune system. When interactions occur between parasites, Plasmodium falciparum or Plasmodium vivax, and the immune system, the body's immune response releases cytokines. Cytokines are produced to regulate the work of the immune system in the inflammatory process. Cytokines that are formed can work proinflammatory or anti-inflammatory. The balance between proinflammatory and anti-inflammatory cytokines is very important and affects changes in hemoglobin levels. Cytokines that play a role in malaria with anemia are varied. The cytokines that play a role are Interleukin (IL)-12, Tumor Necrosis Factor (TNF)- $\alpha$, Interferon (IFN)- $\gamma$, and IL-10. Several studies have found that these four cytokines play a dominant role in malaria with anemia. ${ }^{2,3}$

In 2012, asymptomatic malaria was found in Trenggalek District. Eighteen blood samples of malaria patients who had been cured, were examined microscopically and with single-step polymerase chain reaction (PCR). Five samples were found to contain malaria parasites, although they did not show clinical symptoms. ${ }^{4}$ According to Bousema, et al., asymptomatic malaria is a malaria infection shown by the presence of malaria parasites in the blood of patients who were examined both microscopically and molecularly but did not show clinical symptoms of malaria (asymptomatic). ${ }^{5}$ Parasitemia in asymptomatic malaria usually occured in very low number of patients. ${ }^{6}$

Immunity to malaria is very complex because it involves almost all components of the immune system. Malaria parasites that enter the blood will soon be faced by the body's original immune system by a natural immune response and then a specific immune response. The natural immune response is the first effector in providing resistance to infection. ${ }^{7}$ While the examination of asymptomatic malaria patients showed an increase in IL 10 and a decrease in TNF- $\alpha .{ }^{8}$ Research on pregnant women in Africa also states that high IL-10 levels in infections can protect from clinical symptoms of malaria. IL-10 can also suppress Plasmodium parasitemia. ${ }^{6}$

The presence of asymptomatic malaria can be a source of malaria transmission. Therefore early detection and understanding of the patient's immunity status associated with asymptomatic malaria are important to study. In this study, a diagnosis of asymptomatic malaria will be carried out in malaria patients who have been cured.

\section{Materials and methods}

\section{Study Design and Subject Selection}

The study design was cross-sectional. The study was conducted by taking blood samples and blood smears of subjects suffering from asymptomatic malaria found in Pandean District and Dongko District, Trenggalek District, Jawa Timur Province.

Selected subjects were 30 male, age 21 to 60 years. The inclusion criteria of the study usually subjects who did not show clinical symptoms of malaria, but on blood microscopic examination, Plasmodium was found. All subjects were former malaria patients who had worked in malaria-endemic in Kalimantan Island. All subjects moved to the area of Pandean Health Center and Dongko Health Center in Trenggalek District, Jawa Timur Province in August 2014.

\section{Blood Smear and Hemoglobin Examination}

For IL-10 and TNF- $\alpha$ examination, $3 \mathrm{~mL}$ of blood were drawn from each subject. Two $\mathrm{mL}$ blood were used for making the blood smear and hemoglobin $(\mathrm{Hb})$ examination at Dongko Health Center with hematology analyzer (pocH100i, Sysmex, Kobe, Japan). Then the leftover $1 \mathrm{~mL}$ blood was centrifuged at $3000 \mathrm{rpm}$ for 15 minutes to separate blood cells and plasma. All procedures have been approved by The Health Research Ethics Committee Faculty of Medicine Universitas Airlangga (No. 338/EC/KEPK/FKUA/2014).

\section{IL-10 and TNF- $\alpha$ Examination}

Blood plasma was taken to the Surabaya Tropical Infection Hospital to examine IL-10 and TNF- $\alpha$ levels using LEGEND MAX Human TNF- $\alpha$ enzyme-linked immunosorbent assay (ELISA) Kit (Cat. \#430207, Lot No. B188174, BioLegend, San Diego, CA, USA) and LEGEND MAX Human IL-10 ELISA Kit (Cat \#430607, Lot No. B176715, BioLegend). The plasma was incubated for 15 minutes on the microplate, washed and labelled with biotinylated antibody. After 30 minutes incubation at room temperature, streptavidin-HRP was added, then reacted with 3,3',5,5'-Tetramethylbenzidine. Measurement was performed with a spectrophotometer which was set at $450 \mathrm{~nm}$.

\section{Results}

Among the asymptomatic subjects, age from 21 to 60 years, there were 13 subjects infected by $P$. falciparum, 
16 subjects infected by $P$. vivax and 1 subject infected by both P. falciparum and P. vivax. Average of TNF- $\alpha$ level of the asymptomatic subjects was $24.28 \mathrm{pg} / \mathrm{mL}$, ranging from 6.55 to $218.76 \mathrm{pg} / \mathrm{mL}$. Average of IL-10 level of the asymptomatic subjects was $54.47 \mathrm{pg} / \mathrm{mL}$, ranging from 0.30 to $257.57 \mathrm{pg} / \mathrm{mL}$. Meanwhile in normal subject, the average of IL-10 level was 12.6, ranging from 8.5 to $16.7 \mathrm{pg} / \mathrm{mL}$, and the levels of TNF- $\alpha$ was ranging from $0-1.5 \mathrm{pg} / \mathrm{mL} .{ }^{9}$ There was a significant negative correlation of IL-10 and $\mathrm{Hb}$ $(\mathrm{r}=-0.363 ; p=0.048)$ (Table 1).

Table 1. Relationship Spearman's analysis test for the $\mathbf{H b}$ levels, TNF- $\alpha$ and IL-10.

\begin{tabular}{lcccc}
\hline & $\begin{array}{c}\text { Spearman's } \\
\text { rho }\end{array}$ & Hb & TNF- $\alpha$ & IL-10 \\
\hline $\mathrm{Hb}$ & $\mathrm{r}$ & 1 & 0.002 & -0.363 \\
& $p$ & $\cdot$ & 0.992 & 0.048 \\
$\mathrm{TNF}-\alpha$ & $\mathrm{r}$ & 0.002 & 1 & 0.332 \\
& $p$ & 0.992 &. & 0.073 \\
$\mathrm{IL}-10$ & $\mathrm{r}$ & -0.363 & 0.332 & 1 \\
& $p$ & 0.048 & 0.073 &. \\
\hline
\end{tabular}

Correlation is significant if $p<0.05$ (2-tailed); $\mathrm{r}$ is the correlation coefficient; $\mathrm{Hb}$ : hemoglobin; TNF: tumor necrosis factor; IL: interleukin.

\section{Discussion}

In all subjects, there were no clinical symptoms of malaria and were able to perform routine activities as usual. TNF- $\alpha$ levels were lower than IL-10 levels in patients with asymptomatic malaria. This means that the activation of Th2 cells is more dominant than Th1 cells. These results are consistent with the previous reports, suggesting that there is a positive a significant correlation between TNF- $\alpha$ and IL-10..$^{10,11}$

In this study there was no clinical symptom of anemia (asymptomatic malaria) that usually occurs when the patient has malaria. This could occur because of the high IL-10 level might inhibit the work of Th1 cells and macrophages so that it can reduce the process of erythrocyte damage. ${ }^{12} \mathrm{IL}-$ 10 also contributes to inhibit suppression of bone marrow by TNF- $\alpha$ in producing erythrocytes. ${ }^{13}$ It can be seen that the mean $\mathrm{Hb}$ level of asymptomatic malaria sufferers did not experience a drastic decrease to cause anemia.
Merozoite $P$. falciparum enters the body can activate T lymphocytes into Naive helper T cells $\left(\mathrm{CD}^{+}\right)$and cytotoxic $\mathrm{T}$ cells $\left(\mathrm{CD} 8^{+}\right)$, proliferation and differentiation of $\mathrm{CD} 4^{+}$ Naive helper T cells become Th1 and Th2. Th1 produce IFN- $\gamma$ which activates macrophages produces cytokines including TNF- $\alpha$, Th2 which will produce cytokines including IL-10. The balance of cytokines produced by Th1 (TNF- $\alpha$ ) and cytokines produced by Th2 (IL-10) can determine the severity of the disease. Whereas asymptomatic malaria infection both Th2 and Th1 cells are activated by parasites but Th2 activity is more dominant than Th1. ${ }^{14}$

The patient's $\mathrm{Hb}$ will be increased if the IL-10 level in the patient is high compared to TNF- $\alpha$ levels in the patient's blood serum. This means that TNF- $\alpha$ levels are too high, it can cause many manifestations of disease such as heat, chills and anemia. While IL-10 levels will prevent this from happening because IL-10 is an anti-inflammatory mediator produced by Th2 cells to suppress the activity of Th1 cells. ${ }^{14}$

According to Nussenblatt, et al., in Uganda there was a negative correlation between TNF- $\alpha$ with hemoglobin levels and a positive correlation of IL-10 with hemoglobin levels in acute and uncomplicated patients with falciparum malaria. ${ }^{11}$

In another malaria study by Kurtzhal, et al., also found that falciparum malaria patients found IL-10 could inhibit TNF- $\alpha$ production. In serum, patients with mild or uncomplicated malaria have elevated levels of IL-10 and decreased levels of TNF- $\alpha$, whereas in cerebral malaria high levels of TNF- $\alpha$ are found. ${ }^{15}$

IL-10 increases the proliferation of B cells and the production of immunoglobulins that are necessary for the development and maturation of anti-malaria antibodies that can minimalize clinical symptom.

This study found no clinical symptom like febris and up regulation of TNF- $\alpha$ because IL-10 can act as downregulator of macrophage, reduces antigen presentation, inhibits the production of reactive oxygen intermediarie (ROI) and nitric oxide intermediarie (NOI), prevents Th1 cells from proliferating and suppresses the production of IFN- $\gamma$, IL-6, TNF- $\alpha$ and Granulocyte Macrophage Colony Stimulating Factor (GM-CSF) by T cells. IL-10 also plays an important role in neutralizing the pathology of macrophages by inhibiting IFN- $\gamma$ and TNF- $\alpha$ secretions. ${ }^{13,16,17}$ This can explain in this asymptomatic malaria study where IL-10 levels are higher than TNF- $\alpha$ levels. 


\section{Conclusion}

Levels of IL-10 were higher than levels of TNF- $\alpha$ in the serum of asymptomatic malaria patients in the district of Trenggalek, Province of East Java, Indonesia. There is also found an association between $\mathrm{Hb}$, TNF- $\alpha$ and IL-10 levels in asymptomatic malaria patient.

\section{References}

1. Pemerintah Provinsi Jawa Timur [Internet]. Malaria case in Province of East Java [cited 2014 Nov 14]. Available from: http://www. jatimprov.go.id/.

2. CChaisavaneeyakorn S, Othoro C, Shi YP, Otieno J, Chaiyaroj SC, Lal AA, et al. Relationship between plasma interleukin-12 (IL12) and IL-18 levels and severe malarial anemia in an area of holoendemicity in Western Kenya. Clin Diagn Lab Immunol. 2003; 10: $362-6$

3. Fernandes AAM, Carvalho LJM, Zanini GM, Ventura AMRS, Souza JM, Cotias PM, et al. Similar cytokine response and degrees of anemia in patients with Plasmodium falciparum and Plasmodium vivax infections in Brazilian Amazon Region. Clin Vaccine Immunol. 2008; 15: 650-8.

4. Arwati H, Kusmartisnawati, Poppy, Dachlan YP. Asymptomatic malaria in Trenggalek District, East Java Province as revealed by microscopic examination and single step PCR. Folia Medica Indonesiana. 2013; 49: 150-4.

5. Bousema JT, Gougana LC, Drakeley CJ, Meutstege AM, Okech PA, Akim IMJ, et al. Plasmodium falciparum gametocyte carriage in symptomatic children in western Kenya. Malar J. 2014; 3: 18. doi: 10.1186/1475-2875-3-18.

6. Wilson NO, Bythwood T, Solomon W, Jolly P, Yatich N, Jiang Y, et al. Elevated levels of IL-10 and G-CSF associated with asymptomatic malaria in pregnant women. Infect Dis Obstet Gynecol. 2010; 2010: 317430. doi: $10.1155 / 2010 / 317430$.

7. Nugroho A. Harijanto PN, Datau E.A. Imunologi pada malaria. In: Harijanto PN, ed. Malaria Epidemiologi, Patogenesis, Manifestasi Klinik, \& Penanganan. Jakarta: EGC; 2000. p.128-47.

8. Da Silva. Alterations in cytokines and hematological parameters during the acute and convalescent phases of Plasmodium falciparum and Plasmodium vivax infections. Mem Inst Oswaldo Cruz. 2014; 109(2): 154-62.

9. Kleiner G, Marcuzzi A, Zanin V, Monasta L, Zauli G. Cytokine levels in The serum of healthy subjects. Mediators Inflamm. 2013; 2013: 434010. doi: 10.1155/2013/434010.

10. LutyAJ, Kun JF, Kremsner PG. Mannose-binding lectin plasma levels and gene polymorphism in Plasmodium falciparum malaria. J Infect Dis. 1998; 178: 1221-4.

11. Nussenblatt V, Mukasa G, Metzger A, Ndeezi G, Garrett E, Richard $\mathrm{D}$, et al. Anemia and interleukin-10, tumor necrosis factor alpha, erythropoietin levels among children with acute, uncomplicated Plasmodium falciparum malaria. Clin Diagn Lab Immunol. 2001; 8: 1164-70.

12. Day NP, Hien TT, Schollaardt T, Loc PP, Chuong LV, Chau TT, et al. The prognostic and pathophysiologic role of pro and antiinflammatory cytokines in severe malaria. J Infect Dis. 1999; 180: 1288-97.

13. Malaguarnera L, Musumeci S. The immune response to plasmodium falciparum malaria. Lancet Infect Dis. 2002; 2: 472-8.

14. May H, Nicholas JW. Molecular mechanism of cytoadherence in malaria. Am J Physiol Cell. 1999; 276: C1231-42.

15. Kurtzhal JAL, Adabayeri V, Akanmori BD. Low plasma concentration interleukin 10 in severe malarial anemia compared with cerebral and uncomplicated Malaria. Lancet. 1998; 351: 1768-72.

16. Haldar K, Mohandas N. Malaria, erythrocytic infection, and anemia. Hematology Am Soc Hematol Educ Program. 2009; 2009: 87-93.

17. Phillips RE, Pasvol G. Anaemia of Plasmodium falciparum malaria. Baillieres Clin Haematol. 1992; 5: 315-30. 